\title{
How to Pinpoint Where to Make International Science- Technology Cooperation Most Effectively
}

\author{
Ki-Hoon Jun* \\ Graduate School of Latin American Studies, South Korea \\ *Corresponding author: Ki-Hoon Jun, Graduate School of Latin American Studies, Hankuk University of Foreign \\ Studies, South Korea
}

\begin{abstract}
ARTICLE INFO
Received: \#ebruary 05, 2019

Published: 幽 February 19, 2019

Citation: Ki-Hoon Jun. How to Pinpoint Where to Make International Science-Technology Cooperation Most Effectively. Biomed J Sci \& Tech Res 14(5)-2019. BJSTR. MS.ID.002604.
\end{abstract}

Keywords: S \&T Cooperation; Reciprocity; Hads and Needs; National Research Institutes; Institutes Projects; Detailed Analysis of Technology

\begin{abstract}
Amid increasing significance of Science and Technology (S \& T) cooperation in international relations, here I suggest a strategy to boost its bilateral progress. That is, analyzing very in detail regarding ongoing projects of national institutes of a specific country, and then confirm its drawbacks and needs that can be supplemented by its partner who is not so dominant in power but is leading in different technological fields. With closer look at Chile's ongoing national institutes' projects and its drawbacks/needs that could be covered by South Korea's status, I will show an example telling how grasping detailed technological current priority and exact needs are important for pinpoint where to make cooperation. And this task, of course, should be an academic task, not reserved for policy-makers who cannot afford everything to understand counter-part country's all scientific national projects. To apply this logic to Chile and Korea, I would like to suggest potential areas for further Korea-Chile's STC, by conjecturing on technological traits and needs which are seen from Chilean national institutes' projects, and by comparing them with programs of the same institutes in Korea.
\end{abstract}

My research reveals the follows. Most of economical projects are run by Foundation of Chile having quite sophisticated projects, unlike most foundations doing only financing. Meanwhile, environmental projects and mining are very developed in Chile and thus no much cooperation with Korea would be needed. Conversely, Chile fails to take advantage of its good IT environment for national institutes' programs; no programs using GIS or biomass which are very settled in Korea's governance. Besides, the geographical information's and measurement equipment are another disadvantaged field, leaving potentials for S \& T cooperation. With those analyses, I show how the detailed, apparatuscentered technological analyses of national S \&T projects can provide crucial hints for where and how to cooperate in S \& T, bilaterally.

\section{Introductory Parts}

\section{Foreseeing Needed Areas for Further S \& T Cooperation - That is Researchers' Job}

More recently, numerous studies confirm the increasing influence and significance of international cooperation in science and technology (just to take some exemplary citations, [1-4]. Given that, there might be some needs for certain strategies to make more effective and rapid the processes of boosting bilateral cooperation. In the present paper, I propose an approach for this purpose, remarked by analyzing the comparative advantage and disadvantages of a country's $S \&$ T, manly through the ongoing project of its national scientific institutes. And this analysis should be done in comparison with other country whose overall development is relatively similar, being that in some areas it is more advanced but in other in other S\&T areas. In simpler expression, by comparing technological traits from national institutes, in respect to its counterparts similar in overall development, we can see what this country has more and what it lacks more. In sum, my approach is focusing on national S\&T projects' merits and lacks compared with another country in overall similar progress but quite different 
in specialties. And I would like to assert that such technological comparison in respect to potential S \& $\mathrm{T}$ cooperation counterpartcountry, to the very detailed degree as shown in subsequent analyses, should be a task dealt by academic researchers, not by international-cooperation government authorities.

The reason is simple, as follows. Can the government officials grasp those technological details? Could they spare enough time to specify technology fields deserving most the S \& T technology? It does not seem likely, because that requires acquiring scientific knowledge far from their original careers, as well as fully understanding countries' S \& T development status, needs, and drawbacks. It will be never easy to do so while at the same time struggling with many other exterior-relation affairs. What about the ministry of science? They are to be familiar with basic guideline and focused areas of technology development (for instance, nowadays, Korean governments talk a lot about the 4 th industrial revolution). However, it will be costly for them to thoroughly comprehend many projects developed in high-level institutes and universities where most of new $=\mathrm{S} \& \mathrm{~T}$ are produced. I have said Korean academy paid little attention to detailed technology, and all aforementioned governmental institutions are not capable of handling with it.

So, it remains unclear which technology fields exactly are the best for further cooperation. With few sources predicting to-becooperated technologies, until now Korea-L. A's bilateral STC has been progressed through direct conversation between government officials or the same field institutions. However, it never takes a short time for those diplomatic exchanges, especially the two sides are mutually distant culturally and geographically. And when S \& $\mathrm{T}$ institutes or universities from two countries are cooperating, they have difficulties in breaking inter-disciplinary barriers. Those respects are telling both governments and educational institutions would have certain difficulties and costs in developing bilateral S \& T cooperation's. On the contrary, the S \& T cooperation can be far more boosted when the negotiating parties are provided with exterior knowledge to foresee the most appropriate S \& $T$ area for cooperation. Having and sharing information prior to beginning exchange, the diplomatic process for $\mathrm{S} \& \mathrm{~T}$ can be progressed far more smoothly and fluently. And that is of course what the researchers and academics should do.

\section{National Institutes' Projects: Direct Reflection of National S \& T Development Goals}

Then, how to provide specific-technology needs and haves from the both sides, with enough academic grounds? My choice is: focusing national institutes' projects, for the following reasons. According to Sapre [5], the national institutes are exerting central role for $\mathrm{S} \& \mathrm{~T}$ development in non-Western countries. Besides, in L.A., the executive's power prevails over check-and-balance [6]. Then it is inferred that L.A.'s national institutes will be hardly free from government (executive)'s development schemes, while their project outcome is highly crucial for national socio-economic or industrial developments. Therefore, also the technologies in those institutes' projects can be direct catalysis of national developments. That clarifies that national institutes' project technologies are the most direct hints for S \& T areas for further bilateral cooperation.

\section{Country Selection for the Present Research: Chile, in respect to South Korea}

In this paper, I will focus on Chile, which is providing important spaces for scientific advanced research, represented by its Atacama Desert [7], but also which does not seem to take its full advantage for its own S \& T level. Meanwhile, among all Latin American countries it is the most oriented to external cooperation, including that for S \& T. With those characteristics, this country is quite worth to analyze where to cooperate more. Meanwhile, I decided to set East Asia's South Korea as Chile's counterpart to evaluate its technological relative progress and drawbacks, taking account for the following facts: While Chile's main industries are mining, agriculture and fishery, Korea's main industries are heavy chemical industries and more high-technological industries [8]. But meanwhile, both countries belong to high-income countries [9]. As the potential counterpart for Chilean cooperation, Korea has its own specific. First, even among advanced OECD countries, Korea is known for its very generous investment in R \& D and innovation activities, and as a result it reached to two remarkable achievements out of most other countries' reach -

a. One of the top five countries in the number of patent registration since late 2000s, especially in the biggest oversea markets like U.S.,

b. Furthermore, it is one of the 12 biggest countries in terms of SCI publication [10].

Nevertheless, by choosing Korea as the counterpart of Chile, I never mean any specificity of Korea's significance as cooperation partner for Chile. It is just the example, and I want to say that the same logic of comparative analyses can be applied to any other cooperation pairs of countries.

\section{Importance of Not Overlooking Seemingly Miniscule Components}

Besides, I have to make one more argument: the significance of not overlooking seemingly futile or partial components or products. Sometimes, a whole industry of nation can be determined by a single product; one virtual example is coast-tourism country, where the cruise's technical endurance might determine all the industrial outcomes. This is extremely sophisticated task - the tragic of Sewol-Ho In Korea reminds that only the perfect care can enable cruising for years and for long distances with no accidents; the majority of huge ships are hardly free from obsolescence. Then, how to deliver such technological needs? In relation with this, we should ask two questions:

a. Whether the country's maritime institutes develop the technology within few years, and 
b. If not, then we could ask whether donating or cooperating foreign countries deliver those needs. If the country cannot meet the need by itself, and if its cooperating countries can deliver it, then needs and hopes for TC is highly expected.

\section{Summary of Present Study's Concern}

Then, in this research, I will contemplate projects and programs of national institutes of all fields, along with their technological traits including follows: Till here, I stated the follows:

a. In our age in which the international cooperation for S \& $\mathrm{T}$ is becoming more critical, I suggest a strategy to boost it, by exactly understanding what the country A has more in respect to its potential partner $\mathrm{B}$, and also what it lacks more.

b. Cooperation is also a sort of transaction. And thus, it can be more boosted by understanding what each party needs and affords more, relatively.

c. I emphasize that such detailed comparative analyses should have been an important subject in academic researches; otherwise, the S \& T international cooperation will go on more based on political logics rather than meeting both parties' exact interests and needs.

d. Since national S \& T developments in the third world is often led by national institutes' projects, it is worth to focus on ongoing programs of those organizations.

e. With those approaches' selection, I chose to analyze Chile's national-institutes S \&T status in comparison with South Korea's one, taking account for the two facts:

A. Both countries are similar in economic position, but very distinct in specialized industries, and

B. But meanwhile, both countries are one of the most competitive and open to external cooperation compared with other countries in the same continent. While their common features is likely to facilitate further cooperation in the future, their sharp difference in technological merits and demerits maximize the possible pay-offs by mutual cooperation.

f. In this respect, analyzing what Chile would need and could get from South Korea's S \& T assets, as well as confirming its more advanced programs, will provide a milestone information for boosting their closer cooperation - essentially, it helps to pinpoint and specify the area or issue to concentrate coworking.

\section{Methods of Analyses}

My methods to look at national institutes' projects are as follows. The analysis methods stated below will be used only when necessary and meaningful for understanding of projects and institutes; otherwise, the paper will be too redundant beyond allowed space. Finding technological traits can be made first through searching projects information, taking into account even tiny and partial technological details in that project. And the best areas for $\mathrm{S} \& \mathrm{~T}$ cooperation can be referred from technological limitations in those projects; cooperation comes from needs, and needs come from limitations.

\section{Current status of Projects}

A. Each project's continuity and current status will be seen by website-information update's timeliness

B. Technological Contents

a. My analyses of projects and their technological traits will include:

b. Objects and their components in focus, their measurements, and applied regions

c. While information search will be primarily through institutes' websites,

d. I will make both phone and e-mail inquiry when: webpage provides only basic

e. Information of project schemes, link is not available, no update for more than one year.

f. If even my additional inquiries do not draw sufficient informations,

g. The significance of those projects and their technologies will be largely reduced.

\section{Project Contents' Credibility Check}

The confidence of project information's will be examined when necessary, by contrasting multiple sources.

\section{Exploring Technological Limitations}

Those limitations can be inferred when:

a. There are grounds to argue that the technological tools or schemes are not sufficiently elaborated as the project needs.

b. Compared with Korean institutes' in the same field, lacking certain tools, programs, or processes are observed, and this is likely to substantially affect the project-outcomes or industrial/economic developments.

\section{Main Characteristics of Chilean National Institutes}

Most national institutes in Chile are common in twofold. First, most of them have been established during the government of from 1964 to 1970, preceding famous socialist regimes of Allende. Second, there are relatively more institutes belonging to defense ministry, but their projects are centering on civil convenience or education, rather than military technology. The list of Chilean national public institutes is presented in Table $1^{1}$.

${ }^{1}$ Source: Los Diccionarios y Las Enciclopedias sobre Academico. http://www.esacademic.com. 
Table 1: Chile's national research institutes.

\begin{tabular}{|c|c|c|c|c|}
\hline Names in Spanish & Abbreviation in Spanish & English Translation & Foundation Year & Belonging Ministry \\
\hline $\begin{array}{c}\text { Centro de Información de Recursos } \\
\text { Naturale [11] }\end{array}$ & CIREN & $\begin{array}{l}\text { Information Center for Natural } \\
\text { Resource }\end{array}$ & 1985 & Economy \\
\hline $\begin{array}{l}\text { Centro de Investigación Minera y } \\
\text { Metalúrgica [12] }\end{array}$ & CIMM & $\begin{array}{l}\text { Research Center on the Mining } \\
\text { and Metallurgy }\end{array}$ & 1971 & Mining \\
\hline Comisión Chilena de Energía Nuclear [13] & CChEN & $\begin{array}{l}\text { Chilean Commission on the } \\
\text { Nuclear Energy }\end{array}$ & 1985 & Mining \\
\hline $\begin{array}{c}\text { Corporación de Investigación Tecnológica } \\
{[14]}\end{array}$ & INTEC-Chile & $\begin{array}{l}\text { Technological Research } \\
\text { Corporation }\end{array}$ & 1968 & Economy \\
\hline Fundación Chile [15] & & Foundation of Chile & 1976 & Private Corporation \\
\hline Instituto de Desarrollo Agropecuario [16] & INDAP & $\begin{array}{l}\text { Institute of Agro-pecuary } \\
\text { Development }\end{array}$ & 1962 & Agriculture \\
\hline Instituto de Fomento Pesquero [17] & IFOP & Institute of Fishery Enforcement & 1964 & Economy \\
\hline $\begin{array}{l}\text { Instituto de Investigaciones Agropecuarias } \\
{[18]}\end{array}$ & INIA & $\begin{array}{l}\text { Research and Development } \\
\text { Center on Agro-fishery Industry }\end{array}$ & 1964 & Agriculture \\
\hline Instituto Forestal [19] & INFOR & Foresty Institute & 1965 & Economy. \\
\hline Instuto Geografico militar & IGM & Geo-Military Institute & 1922 & Defense \\
\hline $\begin{array}{l}\text { Servicio Aerofotogramétrico de la Fuerza } \\
\text { Aérea de Chile }\end{array}$ & SAF & $\begin{array}{l}\text { Air Force Institute of Aero } \\
\text { Photography }\end{array}$ & 1915 & $\begin{array}{l}\text { Geomilitary } \\
\text { Information }\end{array}$ \\
\hline $\begin{array}{l}\text { Servicio Hidrográfico y Oceanográfico de } \\
\text { la Armada de Chile (SHOA) [21] }\end{array}$ & SHOA & $\begin{array}{l}\text { Hydrographic and Oceanographic } \\
\text { Service of the Chilean Navy }\end{array}$ & 1874 & $\begin{array}{c}\text { Disaster } \\
\text { Management }\end{array}$ \\
\hline $\begin{array}{l}\text { Servicio Nacional de Geología y } \\
\text { Minería[22] }\end{array}$ & SERNAGEOMIN & $\begin{array}{l}\text { National Geology and Mining } \\
\text { Service }\end{array}$ & 1980 & Minng \\
\hline
\end{tabular}

. In my observation of websites of all those institutes, some of their projects are too-little or too-shortly stated unlike others run by the same institute. There are few reasons to pay equal attention for those projects which are understated by institutions themselves, and thus I will focus on only projects with minimum amount of description. In my observation, neither most of current main projects were explained verbosely. So, I set a bit generous linguistic criterion to consider a project worth to address here-any project stated with one or more paragraphs, each consisted of three or more compound sentences. Summing up all relevant projects of Chilean national institutes, I re-analyzed their technological features by industrial classification (hereafter ICS). Fortunately, or unfortunately, I found that Chile's national institutes' projects were concentrated only in few of industries classified by UN's two-level industrial-classification system [23]-most of them for primary industries, energy safety, along with services of education, information diffusion, technology provision, and health-care.

\section{Primary Industries}

\section{Agriculture}

More to Develop: knowledge-diffusion of cultivation technology, and public use of precision-agriculture in cultivation of fruits, Foundation of Chile pursues nutritional efficiency-enhancement program for Taracapa and other Northern regions, and offers another education program for crop-check - the technology of regular check of crops' status through which the best methods of cultivation is determined. However, the second one: crop-check education program is only for the functional-fruit Maqui. Besides more needs of knowledge-diffusion of agricultural technology, here I will have to quote on precision agriculture or satellite farming. Precision agriculture is for optimizing management decisions and maximizing resource input-output efficiency, through observing crops from satellite - the method called GPS (Global Positioning Satellite). In Korea, since it successfully launched NARO satellite in January 2013, the precision agriculture has prevailed. For example, in April this year, Hong et al. [24] has inferred on temporal and spatial distribution of soil waters and amount of evaporation, in order to evaluate flooding vulnerability in farm lands; along with radar, civil-engineering sluice model, and geographic information system (GIS), the optic satellites were employed in their research. In fact, however, it has been far longer ago that using satellites for agricultural purpose had been discussed using foreign satellite data has begun since 1999, for the part of Korean Ministry of Agriculture Hong et al. [24].

Chilean government also launched the Fasat Charlie for precision agriculture, but it was abandoned by 2015 for obsolescence; launching its substitute was planned for 2017, but still there is no realized actions [25]. Then, currently services for precision agriculture are privatized, costing over $90 \$$ per hectar beyond ordinary peasants' affordance [26]. In Chile by now, the precision agriculture, despite its ground-breaking impact on productivity, is a luxury good. This situation contrasts with Korea where now precision-agriculture is widely used for agricultural policies, helping most small-business farmers in ways like minimizing loss by floods and droughts - for instance, precision-agriculture predicts the least/ most robust crops and lands to the forthcoming disasters, leading 
to optimal choice of cultivation; whether precision-agriculture is public good like in Korea or private good in Chile, will determine the future of the nation's agricultural industry. In pastoral industry, the Institutes of Agro-Fishery Research (INIA, in Spanish abbrevia- tion), is seeking bees' protection from climate change and temperature instability's damages. As other programs below will confirm, many projects of Chile's national institutes are devoted to measurements of climate change's potential defects (Figure 1).
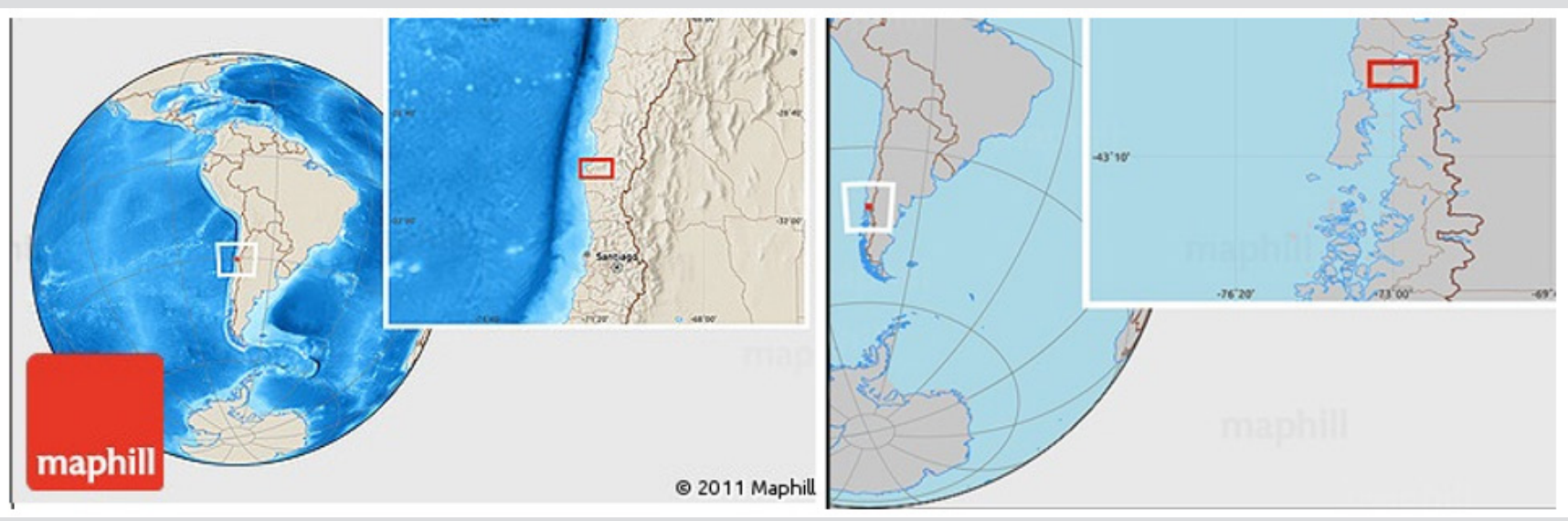

Figure 1: Location of Tongoy and Quillaipe.

\section{Boosting Marketing's of High-Quality Crops}

Amid the strengthening relationship between two continents, since 2000s, there have two mega-trends change in world market's food consumption. First, in China, who is now leading production and consumption in world economy, the demand for high-quality foods have emerged Second, since emergence of academic interest in Bolivia's Quinoa since 1990s and its world-market prevalence since 2000, Latin American functional foods have attracted far more worldwide attentions than before ${ }^{2}$ [3]. Obviously, those two new trends raised

a. More importance of high-quality agriculture products and b. More economic values of health/functional foods. Chile's NRIs took into account both.

In response to trend

a. The Institute for Agro-Fishery Development (Instituto de Desarrollo Agropecuario, INDAP) is focusing On encouraging high-quality crop products' expansions at the national and international market. In response to trend

b. Chile's Institute of Agro-Fishery Research (Instituto de Investigations Agropecuarias, INIA)) is promoting industry of health-curing and functional foods. Further elaborations are provided below.

Table 2: INDAP \& INIA: difference in orientation for boosting primary industries.

\begin{tabular}{|c|c|c|}
\hline & INDAP & ANIA \\
\hline Sectors of support & High-quality crops & Agriculture and Fishery \\
\hline Items of support & Broader recognitions \& sale networks & Diversification, Defects' minimization \\
\hline Focus of support & Domestic & Oversea \\
\hline Targeted market & Regulatory supports & Direct investment \& Scientific researching \\
\hline Main methods of support & & Rods \\
\hline
\end{tabular}

INIA and INDAP's names are very similar, except that one includes 'research' and the other includes 'development'. However, their current program reveal more differences as in the Table 2 [1] For Bolivia's local people, the recent effect of Quinoamerchandising is rather destructive; its excessive exports led to shortage of its domestic stock. for Bolivia's indigenous people, Quinoa has been merely food-for-living, not luxury food. And now some of them cannot have it and starve. Rather than promoting new varieties of crop, the INDAP is focusing on certifying and supporting retails and circulations of high-quality agricultural products. The corresponding programs are twofold. First, it involves establishment of commercial networks for certified trademarks of agricultural products [16], alike Korea's National Agricultural Cooperation Federation $^{3}$ (In another program, it involves more than forty kinds of products - quasi-all agro-pastoral items - including dairy products and honey products. INIA claims to seek 'boosting

${ }^{2}$ For Bolivia's local people, the recent effect of Quinoa-merchandising is rather destructive; its excessive exports led to shortage of its domestic stock. for Bolivia's indigenous people, Quinoa has been merely food-for-living, not luxury food. And now some of them cannot have it, and starve.

${ }^{3}$ Nonghyeop in Korean, https://ibz.nonghyup.com/servlet/CGCN0000S.view 
development and exportation of foods that can help to overcome various illness like chronic disease, heart disease, and regressive disease. For this ultimate goal, they are making direct investments annually - in 2017, 54 billion USD; in 2019, expectedly, 62 billion USD. Meanwhile, their current programs show they are pursuing two ways for their ultimate goals:

\section{Minimizing Loss in Production and Distribution, Through Two Counter-Measures}

Besides, they also claim their engagement in promotion of public-private cooperation for commercial success of high-addedvalue products; however, no further reports on those activities are published on their websites. Even if they do have regular events for that purpose, the institute's focus in overall seems inclined to more diversities and stabilities in productions and distributions, using technological means. Among the aforementioned four programs, further statements are worth for germplasm bank program. That is, it is necessary to explain why INIA is running germplasm bank, instead of gene-bank as most advanced countries are doing. The main difference between two is that, while the gene bank pursues to preserve maps of the whole DNA and genome structure, the germplasm bank allows for mutation. By the full-preservation of DNA/genome structure as aimed by gene-banks, we can grasp how existing-species are biologically organized and are living, and for the sake of public interests or medical purpose we could transplant and employ some parts of one species' DNA-structure to help human beings' or other species' survival/reproduction. In any case, the very species' evolution shapes are not of primary interests in gene banks.

If allowing mutations is due to lack of resources to prevent it, then they had better not to run germplasm bank; running it in itself would require a lot of resources in terms of finance and labors. In other words, allowing mutations is for some reasons, not for incapability to prevent it. Then, what are the reasons for that? Here, I would like to point out that the mutating individuals becomes different genetically and biologically, from other individuals of originally identical species. With such withinspecies differentiation, an originally single species becomes more variant at later time, this is a way of diversification. In this sense, the germplasm bank's allowing mutation implies that the institute primarily aims would be further diversifying current species, rather than mapping and transplanting their genetic structures. There are already biological diversities in Chile, with more than 30 thousand species under geographic diversity including huge ocean, mountain area, savanna, and tropical regions. And further increase of such diversity is Chilean government's aim, with plan of creating new 170 thousand species in years. Since the developed species include not only commercial crops but also insects and non-edible crops, the priority seems to be in biological diversity itself rather than economic profits. According to the institute, however, current local species are already of 4,000 kinds; this means, although only parts of those plants are in the bank, still a lot of economic benefits are expected.

\section{Fishery and Aquaculture}

Aquaculture programs, by Foundation of Chile: The programs run by the Foundation of Chile (Fundación Chile), unlike those of typical foundations, is never limited to financing other institutions. Rather, it is developing projects across most sectors of primaryindustry sector as well as organizational strategy program. The programs for fishery-aquaculture by Foundation Chile are quite variegate, covering weights-increasing, diversification, aquacultureskills diffusion, medical care, and international treaties. While their planned regional coverage is more than a half of the whole country, however, the kind of involved fishes is relatively limited. When looking at programs by region, aquaculture-skill education is mostly for the Northern region - especially for the coast-city Tongoy. On the contrary, in Quillaipe, closer to middle part of country, they pursue two objectives: Regarding fish-kind aquaculture program, the most recent one was for honnibecroak. In this program, multiple honnibecroakers are grown being trapped in reservoir, with artificial increase of their weights.

The weight-increasing scheme is quite well-elaborated, being set according to honnibecroaker's various age levels; e.g.> $40 \mathrm{~g}$ for the very young kind, $2.5 \mathrm{~kg}$ for adult. However, since 2009 no further reports are provided, and we cannot know whether and how well the program is currently running. When it comes to region-specific aquaculture program, programs in northern-area is focusing on aquaculture skills, especially in coast-city Tongoy. On the contrary, in the Quillaipe region, the objectives are to develop two subjects -

a. Fishery distribution from Manila- clam to cod, as well as frozen pollack,

\section{b. Vaccinal and medical care ${ }^{4}$.}

International Agreements in fishery-aquaculture, by Foundation of Chile: On the other hand, Foundation of Chile lists foreign countries who have clapped up the agreement in fishery field, as follows. Among those countries, quite a lot like Morocco, Ecuador, Norway, China, U.S., and Iceland are main exporters of fish toward European countries. That is, Chile has clapped up agreements largely with exporters toward Europe; considering that, it is expected that exportation increase in Korea's fishery will facilitate its cooperation with Chile in corresponding areas.

Information Service and Researching by IFOP: While Foundation of Chile's fishery-aquaculture programs are directly involved in workplace, the data publication and experiments are led by the institutes of Fishery Enforcement (Instituto de Fomento Pesquero, IFOP). Every week, IFOP discloses the data on the amount of fishery catch; however, the classification is made by reserving and processing (like canning or cocking-oil addition), not the kind of fishes. By missing fish-kind classification, a lot of information is

\footnotetext{
${ }^{4}$ In this region, the most frequent fish disease is decreasing amberjack and its growth stagnation, which are caused by sand skipper, a parasite.
} 
lost. If it had been made, each fish's annual or seasonal path could have been analyzed and predicted; this would not only facilitate fishing and aquacultures in the future, but also tell about climate trends in the sea. Moreover, knowledge diversified by fish kinds would facilitate each fish item's commercialization and discussion in the trade-negotiation table. On the other hand, the Laboratory of Experiment on Fish's Age Growth (labooratorio de la edad y crecimiento) makes experiments on maritime species' age and growth [17], and the species include various subjects including fishery morphology. However, the used equipment are far from technically sophisticated; they are too ordinary ones - microscope, multi-dimensional microscope, camera, personal computer, monitors, and software Instituto Fomento de Pesquero ${ }^{5}$.

Furthermore, the used microscope is Olympus CX31, which is for ordinary people's life in Korea. It is dubious that those general tools will be enough to maximize analysis precision - how well can they make precise anatomy, with mere ordinary tools in our standard? In sum, there are two limitations in projects run by Institutes of Fishery Enforcement. First one is lack of data by fish-kinds causing loss of information critical for promoting market, trade-agreements, meteorology, and oceanography. Second limitation is sophistication level of tools for Fish-Age Growth Laboratory - too ordinary to make full precision. Those limitations cast possible needs, leaving rooms for TC on fishery analyses technology, in close future.

\section{Mining}

For the industry of mining and metallurgy, there are four national institutes:

a. Abbreviated as NGM in this paper However, the first one's task is mainly on diffusion of natural-resource information's, without running additional projects.

b. The second one, on the other hand, is by now almost inactive; previously it worked for CODELCO (Chilean National Copper Corporation)'s renovations, but now its need disappeared since CODELCO has its own organism for that.

Therefore, most mining-related projects are led by the rest two institutes - while Foundation of Chile pursues promoting high-quality human resource for mining, the NGM works for promoting technologies of extracting and processing mineral resources. Programs by Foundation of Chile - Promotion of Mining Expertise: Currently, Foundation of Chile is running the following programs for promoting mining industry. Among them, the most central project is National Human Resource Certificate (Marco Nacional de Cualidades):

A. National Human Resource Certificate (Marco Nacional de Cualidades). By promoting high-level experts for the mining industry, and by matching them with mining corporations, the
Foundation aims the supply-demand equilibrium in the mining labor, and by extension the development of whole labor market. In Chile, mining sector takes over 12 percent of total GDP, urging the Foundation to make mining-related programs very deliberately.

In the program "National Human Resource Certificate", the Foundation seeks to develop, and to bring equilibrium on supplydemand of mining-labor market. For that purpose, the Foundation's prioritized task is promoting high-level experts of mining industry. This program is extremely well-organized, addressing thoroughly multi-faceted parts of mining capacities and processes, as follows. First, the subjects of evaluation include not only product-managing capacity, but also education, evaluation, and by extension the ability to interact with civil/interest groups. Secondly, the handbook series on the mining extraction ${ }^{6}$, the education contents cover coping styles and required educations in each process of mining works like: explosion, exploration, disposition and fissuring of rocks. Lastly, the certificated capacity levels are with no less than 5-step levels: from maneuver work, to chief supervisor. Since Chile's industry level is more advanced than that of other L.A. countries [27], also the level of technological skills learnt by job-seeks is expected to be very elaborated. With those all considerations, the Foundation of Chile is running mining-related programs for expert promotion, equipped with thorough and also well-detailed capacities and attitudes in various steps and spots in a mining site.

Laboratory projects: By Institute of National Service Center on Geology and Mining: The Institute of National Service Center on Geology and Mining - Servicio Nacional de Geología y Minería, Sernageomin - is mainly engaged on the tasks like listening to demands from miners, managing land-registry, and mining concessions. Meanwhile, it has totally six laboratories for the more effective mining development, specialized in the followings: geographic transformations of mining lands, measuring chemical substance for mining, and mining resources' purification through chemical dispositions. Those laboratories declare that Chile is the most advanced in L.A. in chemical analyses for mining exploration, and especially in the technology of $\mathrm{K}-\mathrm{Ar}$ (or potasium-argon) measurement - this regards chronological measurements of radioactive decays. Among them, the laboratory of geochronology (Laboratorio de la Geocronologia), the Laboratory of Ultravioletrays and Minerology (Laboratorio de Rayos X y Mineralogía), are providing service of chronological measurement of minings, with methods like heating, dissolution, and rays penetration. The fee for a service ranges from 14-23 $\mathrm{UF}^{7}(500-900 \$)$ [28]. This price does not seem too expensive, taking account for the level of technology applied for mining analyses. Along with mining-expert programs run by Foundation of Chile, the aforementioned technological development makes it above makes it clear that Chile is very capable

\footnotetext{
${ }^{5}$ Please refer to: http://www.ifop.cl/laboratorioedadycrecimiento/tecnologia/

${ }^{6}$ Source: http://www.ccm.cl/marco-de-cualificaciones/

${ }^{7} \mathrm{UF}$ (Unidad de Fomento - Unity of Enforcement) is Chilean monetary which is designed to vary according to inflation, and is used only for financial accounts. By 2016, 1 UF is of 26,347 Chilean pesos. which corresponds to about 40\$ [38].
} 
of developing mining technologies on its own. Thus, the mining is the least needed area for Korea-Chile cooperation; at least there is no need for the part of Chile.

Service Industries - Education, Information, and Technology

\section{Education and Information Service}

Geography: The knowledge-diffusion and education in geography are led by the Geo-Military Institute (Instituto Geográfico Militar, IGM). Despite its name and its belonging to the Ministry of Defense, the IGM's most programs have little to do with military technology. Its primary focus is on the diffusion of geographical knowledges, including geographic education to the public, publishing-books on historical territory divisions, and creating various types of maps. Therefore, it is rather 'geography' institute than 'military' institute, being more open to the public than typical military institutes are. However, compared with Korean geography institutes, the level of its technology sophistication leaves room for further development. The main difference comes from the use of GIS, whose role is very central in nowadays' geographical studies, and also for digital governance and economy. Its definition in itself says so: the system not only includes map locations, but a variety of other geographic informations; that includes human resource's circulation, traffic, retailing, population movement, inter-regional consumption, and geographical inclination trait.

In Korea, its usage and application are now very general not only for geographical research but also for marketing and local administration at the nationwide level. The national interest is also quite intensive - by, more than 250,000 searches have been recorded on Korean Google's search. It is not of the case for Chile. with little interests in GIS (Sistema de Información Geográfica in Spanish); by the same date of the 1st June 2017, only 19,400 searches have been recorded with Chilean domain (*.cl), less than a tenth of Korea's record. While IGM is taking a central role in Chile's national geographical projects, due to low-level application of GIS, its programs' contributions are limited to national history and geography; no application is made for governance and economy as in Korea. Although the need does not seem so urgent, in the future there might be chance for military technology cooperation between Korea and Chile, based on GIS technologies.

Organization Renovations: Besides primary-industries program, the Foundation of Chile runs also those for organizational innovations. Unlike the institute's mining programs, however, those human resource programs do not seem well-organized. The institute's website only quoted on importance of considering organizational dynamics, and very-general theoretical frames. To supplement information, I attempted at phone-call with the responsible personnel. However, the answer was that no further information than basic mechanism maps can be provided. This leads to implication that the level of programs involving management strategies and enterprise organization, when compared with private consulting companies, remains superficial.

\section{Industries of Energy Resources}

\section{Electricity Supply}

Technological Research Corporation (Corporación de Investigación Tecnológica, INTEC-Chile) is currently run by the private company called 'Amergy'. Amergy is cooperating with many multinational companies including GE and Siemens, for the following services:

a. Data consulting and research support for the electricityrelated projects,

b. Assembly and exhibition of electronic components,

c. Establishment of auto-charging and auto-discharging electronic system.

Besides, the company is running tasks like:

a. Maintaining safeties and efficiencies in the electricityrelated workplace and substation,

b. Switching location of electricity-supply circuits, and

c. Running plants. In overall, Amargy's business focuses on stability and safety in the electricity supply. However, while I found those business-information concrete enough, I could not find information's on measuring equipment. This lack of measuring-equipment information is contrasting with Korea Electronic Corporation's measuring-equipment disclosing all relevant information's.

\section{Forestry Institute (Instituto Forestal , INFOR)}

It was established in 1965 and currently belongs to the Ministry of Economy. According to five reports viewable via website, current projects are focusing on minimizing loss of climate change and forest destruction. There seems no project of developing natural-resource development. In relation with this, it is necessary to mention on the forest resources' usage in Chile and Korea. According to Gardner \& Eastin [29], the native forest is taking over 17.8 percent of Chile's whole territory, with squares of $134,700 \mathrm{~km}$; this corresponds to 1.35 times of South Korea's whole territory. Besides, the authors also remark that Chile's both climates and soil conditions are in favor of forest resource's commercialization (p.3). Despite such width, the forestry industry takes only 3 percent in Chile's GDP and only 10 percent of total exportation [29]. This feature makes the industry humble, when compared with mining industry taking over 12 percent of GDP. This is partly due to that Chile's Forestry Institute (Instituto Forestal, INFOR), is mostly focusing on Chilean forests' protection from climate change's damages and forestal destruction, rather than its economic explotation. There seems no project of developing natural-resource development. In relation with this, it is necessary to mention on the forest resources' usage in Chile and Korea.

Unlike the rest of world diversifying alternative-energy industries, Chile is relying only on solar energy industry [30]. Chile's current priorities are also more set on increasing efficiencies of solar 
energy; this plan has been largely achieved by joint projects with large private companies called Espejo de Tarapacá (EdT), a grandscale infrastructure project in which 300 MW pump hydro-plants establishing a large storage system, enabling longer preservation and use of solar energy. With this progress, Chile does not seem to feel urgency for diversifying alternative energy resources beyond solar energy. That explains Chile's little interest in economic use of forestal resources; even the Ministry of Forestry's reports are not considering plans of forestry resources' usage, only except CO2 absorption by cinnamon [31]. Furthermore, in Chile the land corresponding Switzerland's territory is still set as protection area. However, despite Chile's strong tradition of solar-energy reliance and natural-preservation perspective on forestal resources, Korea's case still leaves room for further use of Chile's forestal resource and chance for Korea-Chile's STC for that. Korea lacks far more forestry resources and lands than Chile, but it has successfully developed energetic reproduction technology using biomass; biomass means the set of animals and plants which produce chemical energies including photosynthesis.

Those biomasses' distribution data is fully prepared with extremely precise fuel production data [32], assuring the use of biomass as alternative energy. A similar development occurred also in Chile, though at regional level; in Tarapaca, a region located at Chile's northern border with Bolivia, the Foundation of Chile created full maps of vegetation; with this, the biomass database establishment in Chile does not seem impossible - the only missing is data on chemical emission by those vegetations. On balance, the difference between Korea and Chile's energy development mostly comes from policy tradition rather than technological gaps. Until now, the biomass in Chile is simply an indicator showing forest preservation, based on the number of survived animals and plants which consist biomass system. However, the case of Tarapaca's vegetation map leaves room for further progress in biomass system in Chile, which can be also facilitated by Chile's relatively developed IT environment [33]. Therefore, when economic needs overcome policy traditions, there remain rooms for rooms for further KoreaChile cooperation on the biomass, probably through the form of transplantation. Technologically, this is already possible sufficiently, with Chile's good IT environment and similar achievements at regional level; The only thing to remain is Chilean government's perception of needs.

\section{Public Diffusion of technology}

Application of Aero-Photography Technology, by SAF: According to the Institute of Aero Photography by Chilean Air Force - Servicio Aerofotogramétrico de la Fuerza Aérea de Chile, SAF - its aero-photographic technology is being used not only for governmental plans like prevention of natural disasters and forest fire, but also for applications in industries including agriculture and forestry. However, it does not seem that Chile is making most of this technology, for following reasons. First, there are few real examples of industrial application, while the institute's webpage only quotes that its technology contributes to the development of market which is fundamental for national industries; there are no further specifications on the market areas. Furthermore, all applied industries were only of forestry, not agriculture; they include forestfire extinction, hydro-resource management, forest preservation, and prevention of vegetation illness. Another source of doubts comes from out-datedness of information; the institute claimed to be using the satellite Fasat-Charlie, which was abandoned by 2015. In overall, there are many doubts on the applications of aerophotography as the primary pursuit of the institute.

Agriculture: Diffusion of crop-check education, but lack of precision-agriculture application: Crop-check is the technology of checking the status of crops, to learn the best methods of cultivation. Its program is currently run by Foundation of Chile. However, it is offered only for a single crop Maqui. Having chosen Maqui for technology diffusion seems due to that it is one of Chile's most representative functional foods. That is, crop-check program for Maqui is part of Chilean priority on functional foods' worldmarket expansion. While maqui has become rapidly Chile's top export item [34], no public information sources disclose the share of household growing in Chile's agricultural sector. Therefore, its social implication still is to be questioned. On the other hand, Chile could have enjoyed diffusion of higher-level technology than mere manual crop-checking-precision-agriculture, which is now taking a influential role for policy-making in Korea. It is technique of optimizing management decisions and maximizing resource input-output efficiency, through observing crops from satellite - the method called GPS (Global Positioning Satellite). In Korea, since it successfully launched NARO satellite in January 2013, the precision agriculture has prevailed.

For example, in April this year, Hong et al. [35] inferred on temporal and spatial distribution of soil waters and amount of evaporation, in order to evaluate flooding vulnerability in farm lands; along with radar, civil-engineering sluice model, and geographic information system (GIS), the optic satellites was employed in their research. In fact, however, it has been far longer ago that using satellites for agricultural purpose had been discussed [36], using foreign satellite data has begun since 1999, for the part of Korean Ministry of Agriculture [35]. Chilean government also launched the satellite Fasat Charlie by 2011, for precision-agriculture; however, it was abandoned by 2015 for obsolescence. Launching its substitute was planned for 2017 (according to EFE), but still there are no real progress [25]. Without national satellite, now the services for precision-agriculture in Chile are entirely privatized, with price of $90 \$$ per hectar [26] out of small-farm peasants' affordance. Being offered only as private service, the precision agriculture in Chile is never counted in national agricultural policy and administrations. This contrasts with Korean government who is managing agricultural satellite exploration as a kind of public goods, for precision of its policies. 
There remain doubts on whether and how much only providing crop-check skills can contribute to Chile's goals of dominating global foods of functional foods. Although it is the industry largely influenced by natural conditions, the competition in global market will call for further technological efficiencies; this means that Chile cannot preclude the need for precision agriculture for its top-crop industries, being that its contribution to productivity is far more thorough and radical than manual know-how of crop-checking. In that respect, there are room for STC between Korea and Chile in precision agriculture field - Korea has been advanced so much, while Chile cannot preclude its needs.

\section{Welfare and Health-Care}

\section{Health-Care: Prevention of Radioactive Risk}

While nuclear energy is not of primary alternative resource in Chile, the health-care service has developed protection system from its risk - radioactive exposure. It is led by Chilean Commission on Nuclear Energy (Comisión Chilena de Energía Nuclear, CchEN). Unlike the name sounds, nuclear energy development is not of its priority. The institute primarily pursues the health-care service related with radioactive risks. The most-used service is radioactiveexposure diagnosis at relatively cheap price which is no more than 9 USD per month [37]. It also provides medical-care service for workers who are chronically exposed to radioactive exposures, but costing far more than diagnosis; a thorough corporation examination costs 232,000 Chilean pesos (approximately 37 USD), and a urinal examination costing no less than 53,500 pesos (approximately 80 USD)

\section{Summary and Discussion}

\section{Summary on Chilean Institutes' Technological Traits and Needs for Cooperation}

Beside aforementioned common factors on establishments, the technological characteristics of Chile's national institutes can be summarized as follows.

Advantaged Technology Fields with Few Needs for Cooperation: Chile is very advanced in the following areas, leaving few needs for cooperation with Korea:
a. Radioactive safety
b. Mining
c. Forestal preservation
d. Climate change counter-measurement.
A. Projects with Economic Pursuits

The projects for economic sake include follows.

a. Fishery and aquaculture: gathering fish-catching data and measuring fish-shapes b. Agriculture: Agricultural products diversification through genetic means, Boosting high-quality crops exports and marketing through certification and assisting store expansions. However, over a half of those projects are led by a single institution - Foundation of Chile. Furthermore, those projects are limited to only primary industries; there are few commercial projects for manufacture and tertiary industries, leaving rooms for more STC with Korea. Furthermore, the number is relatively few.

\section{B. Priority of Environment over Economy}

Rather than seeking economic benefits, Chilean institutes are more inclined to environmental projects, especially in relation with climate changes.

C. Technological Fields with Korean Advantage and Chilean Needs

D. The following areas are where Korea is highly advanced while Chile's level does not entirely to the original purposes of institutes and their programs.

a. Those areas are where the most potentials for STC is observed.
b. Promotion and education of organizational strategy
c. Equipment's for electric safety management
d. Equipment's for measuring fish-shapes
e. Geographic Information System, with special focus on its application for military geography,

f. Biomass as source for alternative energy, expanding its database information

g. Public use and policy use of satellite and aerophotographic technologies

Only except the first one - organizational management-, the rest involves either measuring equipment, or geographic information.

\section{B. Discussion}

The present study aimed to expand possibilities for S\&T cooperation between Korea and Chile, with detailed technological features in ongoing projects of Chilean institutes. While previous Korean studies on STC have exclusively focused on macro-indicators of L.A.'s S \&T and its environment, the present study was the first attempt to provide information's on technological areas with the most potentials, in anticipation prior to diplomatic discussions has it has been until now. This will largely reduce burden and process needs when Korea and Chile begin diplomatic conversations for new STC, because unlike the past the two parties already have options and information's on possible areas to cooperate. Furthermore, since specific technological areas from diverse fields are informed, 
the disciplinary barriers can be also overcome; therefore, the institutions developing STC no longer must be from similar fields. With all those advantages, this paper can make contributions to the more swift, more effective, and more diverse STC between Korea and Chile in the future.

The main limitation of this paper is not addressing on the way of cooperation - for example, either in the form of grant, or in the form of credit assistance. This is left to further studies. On the other hand, to make most of my attempt of specifying/clarifying areas for best STC, keeping track of update information is necessary; this means, admittedly, this research cannot be the final-versioned clue, when another STC negotiation is made far later between Korea and Chile. Despite those limitations, my first attempt will contribute to finding various and more specific technological areas for further STC between Korea and Chile, more efficiently.

\section{Final Remarks}

In this paper, I suggested that the $S \& \mathrm{~T}$ cooperation can be best boosted when each one's needs and capacities are fully revealed, and they know how to match it. Simply speaking, knowing one's own needs and the foreign sources to meet those needs, the synergy effect of cooperation will be the optium. That explains why I focused a country (Chile)'s drawbacks and limitations from ongoing scientific-development projects and how it can be covered by its cooperation-partner Korea's technological traits. Inn this way, in my view, the basic nature of remark international S \& cooperation is specifying similarity and different conditions, which allows the optimum mutual complements between two. And there is no reason to limit such logic to those addressed two countries only - for any other pair of countries attempting for mutual S \& T cooperation with relatively equal status, the same kind of analyses can help a lot to boost the $S \&$ T cooperation, by precising each one's needs and meets. In \$my own estimation, I do not think my approach is not very surprising - it is based on common sense that the best help comes when one knows what to need and where to meet. To speak another feature in my approach, I tried to find those what they are doing and what they need more in S \& T through national institutes projects according to Sapre's argument. Despite partially simplistic feature in my approach, nevertheless, I am confident that my very detailed look at those technological progress, needs, and possibility for. To take a counter-example, many studies focus only on super macro-indicators like R \& D, productivity, and advantage and drawbacks in infrastructure. On contrast, my approach involves the real products, which might determine the whole nation's technological status. With closer look at detailed national institutes' projects, we can see the products or items as the locus for S \&T leap. And then, we can specify more swiftly the products or items as subjects for international $S \& T$ cooperation - not just theoretical and friendly agreement, but specific plan on where and for what to invest to cooperate. by such specification of products/components/items/business as target for further S \& T international cooperation, the researchers can make more critical roles on promoting S \& $\mathrm{T}$ cooperation agreements and advances among countries.

\section{Acknowledgment}

I would like to express my special gratitude to my two professors from Hankuk University of Foreign Studies (HUFS). Prof. Won-Ho Kim, by the end of 2016 had led a government-policy project for ODA with analyses about Bolivia, Peru, and Paraguay's national S \& $\mathrm{T}$ development scheme, in a comprehensive manner. I was one of its members and could finish everything well with his back-up for many parts. And this project outcome is a basis for my extended approach for Chile in the present article.

And I say also thanks to prof. Ki-Su Kwon, expert of Latin American FDI and Brazilian economy. After collecting fullinformation's about Chilean institutes' projects, he gave me a crucial tip to re-organize them according to industry-specific accounts. This added my article's sense in terms of national-economy implication, and furthermore enabled coherent summaries industry-byindustry. I hope the aspiration having started from their helps will reach to also other $\mathrm{S} \& \mathrm{~T}$ cooperation researchers, including others than those addressing Latin America.

\section{References}

1. Andrade PA, De Carvalho DBB (2015) International cooperation for science and technology development: a way forward for equity in health. História, Ciências, Saúde-Manguinhos 22(1): 49-67.

2. Serger SS, Remøe SO (2012) International Cooperation in Science, Technology and Innovation: Strategies for a Changing World.

3. Wagner CS, Yezril AS (2000) Hassell International cooperation in research and development: An update to an inventory of US government spending.

4. Prange Gstöhl H (2010) International Science and Technology Cooperation in a Globalized World: The External Dimension of the European Research Area. Edward Elgar Publishing, UK.

5. PM Sapre (2000) Realizing the potential of management and leadership: toward a synthesis of Western and indigenous perspectives in the modernization of non-Western societies. Int J Leadersh Educ 3(3): 293305 .

6. Stein E (1998) Fiscal decentralization and government size in Latin America.

7. Dixon R (2015) Stargazing in Chile: dark skies in the Atacama desert. The Guardian, 1-13.

8. TO of E Complexity, OEC - Chile (CHL) Exports, Imports, and Trade Partners.

9. (2019) Databank, Overall data about Chile, World Bank Data Site.

10.Chung S (2011) Innovation, competitiveness, and growth: Korean experiences.

11. (2019) CIREN.

12. (2019) CIMM.

13. (2019) Comisión Chilena de Energía Nuclear.

14. (2019) INTEC-Chile.

15. Humano D, Ventures C (2019) Fundacion Chile.

16. (2017) INDAP, Red de Tiendas Mundo Rural.

17. IF de Pesquero (2017) Laboratorio de la edad y Crecimiento. 
18. Inia I (2019) Instituto de Investigaciones Agropecuarias.

19. Forestal I, Forestal B (2019) Instituto Forestal.

20. (2018) Servicio Aerofotogramétrico de la Fuerza Aérea de Chile.

21. Servicio Hidrográfico Oceanográfico de la Armada de Chile.

22. SERNAGEOMIN-Servicio Nacional de Geología y Minería.

23. (2011) OECD, Isic Rev. 3 Technology Intensity Definition. Dir Sci Technol Ind 6.

24. Han G, Kim IH, Hong S, Jeong B, Lee G, Park S (2015) The evaluation of sinked farmland and vulnerability to the flooding.

25. Planas A (2017) Chile evalúa tres alternativas para reemplazar el Fasat Charlie. Infodefensa, v, Santiago.

26. Agroprecision, Agroprecision.

27. Beñat Bilbao-Osorio TEIU (2014) Regional Director for Latin America and The Caribbean. Top 10 most competitive economies in Latin America and the Caribbean.pdf. World Economic Forum 2014.

28. De GL (2012) Analisis y Precios.

29. Gardner SL, Eastin IL (2002) Chile’S Forest Products Industry: A Country Profile.

30. CEPAL N (2015) Transnational corporations and the environment, in Foreign Direct Investment in Latin America and the Caribbean 2015: 104-133.

\section{ISSN: 2574-1241}

DOI: 10.26717.BJSTR.2019.14.002604

Ki-Hoon Jun. Biomed J Sci \& Tech Res

(c) (i) This work is licensed under Creative

Submission Link: https://biomedres.us/submit-manuscript.php
31. Bahamondez C, Rodrigo Guiñez, Yasna Rojas, Rodrigo Sagardía, Vergara G (2016) Reporte 'Ecosistemas Forestales Y La Mitigación al Cambio Climático: Cartografia de Bosques Degradados de Bosques Siempreverde y Complementacion de Indicadores de Degradacion en Bosques de Roble-Rauli-Cohue - Región de Los Ríos.

32. Son Y, Jong Chang Kim, Lee KH, Kim R (2007) Forest Biomass Assessment in Korea (Urinara Sallim Baiomaeseu Jawon Pyeongga).

33. De D Ferranti (2002) From Natural Resources to the Knowledge Economy: Teade and Job Quality.

34. Alonso JR (2015) Maqui (Aristotelia chilensis): a Chilean nutraceutical of medicinal relevance). Food Chem 5(2): 673-751.

35. Hong SY (2015) Assessment of land water balance and flood vulnerability using remote sensing (Wongyeoktamsareul Iyonghan Nonggyeongji Mulsuji Mit Chimsuchwiyakseong Pyeongga).

36. Kwon 0, Kim J (2007) Feasibility of Utilizing Satellite Images for Agricultural Outlook (Wiseongjeongboui Nongeopgwancheuk Hwaryong Tadangseonggwa Chujin Jeollyak).

37. De R CC (2017) Nuclear, Servicios de Radiomedicina.

38. B (Banco C De Chile) Base de Datos Estadisticos.

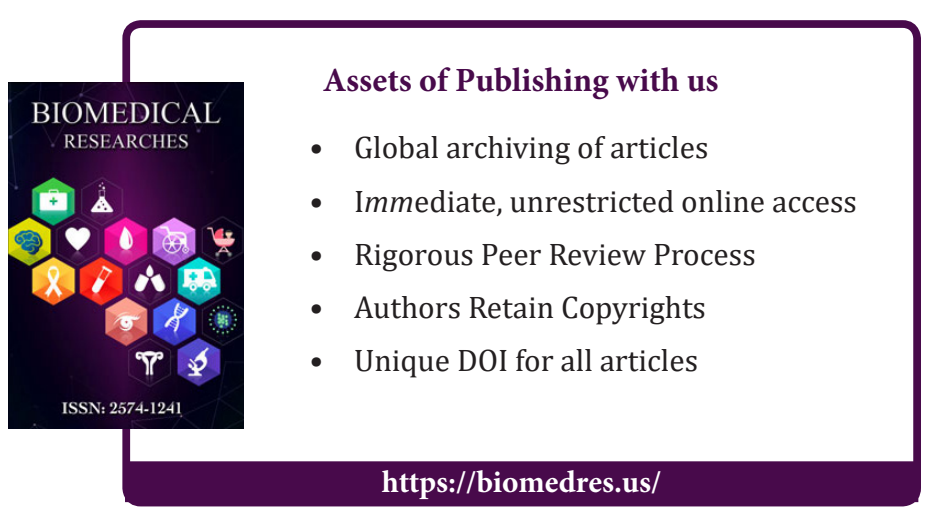

